\title{
Mineral and Vegetation Maps of the Bodie Hills, Sweetwater Mountains, and Wassuk Range, California/Nevada, Generated from ASTER Satellite Data
}

By Barnaby W. Rockwell

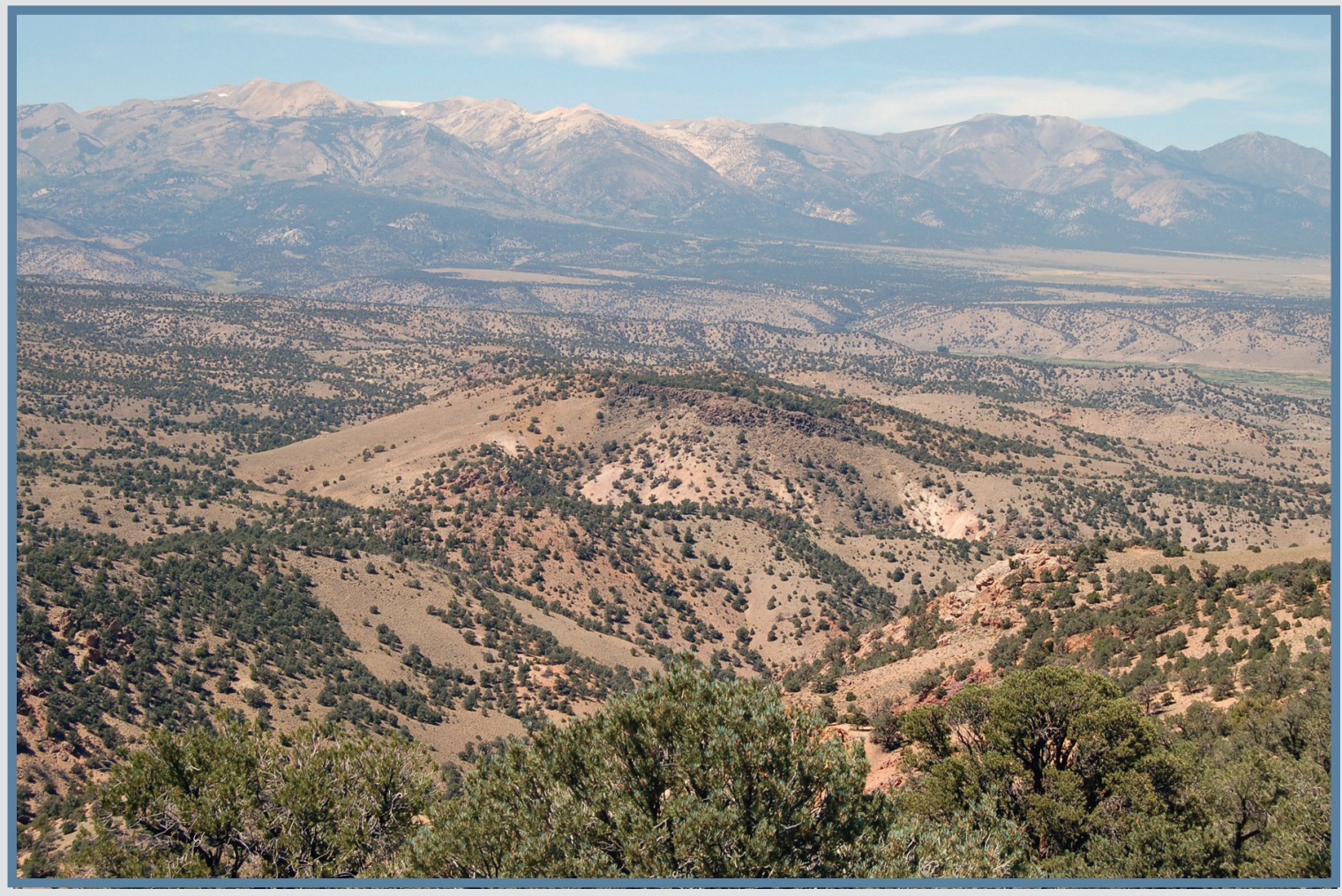

Pamphlet to accompany Scientific Investigations Map 3104

U.S. Department of the Interior

U.S. Geological Survey 


\title{
U.S. Department of the Interior KEN SALAZAR, Secretary
}

\section{U.S. Geological Survey Marcia K. McNutt, Director}

\section{U.S. Geological Survey, Reston, Virginia: 2010}

\author{
About USGS Products \\ For product and ordering information: \\ World Wide Web: http://www.usgs.gov/pubprod \\ Telephone: 1-888-ASK-USGS \\ For more information on the USGS - the Federal source for science about the Earth, its natural and \\ living resources, natural hazards, and the environment: \\ World Wide Web: http://www.usgs.gov \\ Telephone: 1-888-ASK-USGS
}

\author{
About this Product \\ Publishing support provided by: \\ Denver Publishing Service Center, Denver, Colorado \\ For more information concerning this publication, contact: \\ Team Chief Scientist, USGS Central Region Mineral Resources Team \\ Box 25046, Mail Stop 973 \\ Denver Federal Center \\ Denver, C0 80225-0046 \\ (303) 236-1562 \\ Or visit the Central Region Mineral Resources Team Web site at: \\ http://minerals.usgs.gov
}

Cover photograph: View of Sweetwater Mountains in background from the Red Wash Creek alteration zone in the northern Bodie Hills. Floodplain of the East Walker River is at center right. View is towards the west-northwest.

Suggested citation: Rockwell, B.W., 2010, Mineral and vegetation maps of the Bodie Hills, Sweetwater Mountains, and Wassuk Range, California/Nevada, generated from ASTER satellite data: U.S. Geological Survey Scientific Investigations Map 3104, scale 1:62,000, 4 plates, pamphlet, $5 \mathrm{p}$.

Any use of trade, product, or firm names is for descriptive purposes only and does not imply endorsement by the U.S. Government.

Although this report is in the public domain, permission must be secured from the individual copyright owners to reproduce any copyrighted materials contained within this report. 


\section{Contents}

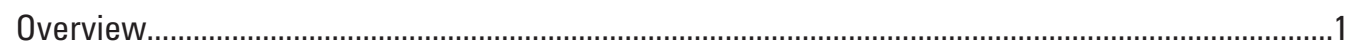

Overall Purpose of Maps .......................................................................................................................

List of ERDAS Imagine Raster Image Files Included in this Publication ..........................................1

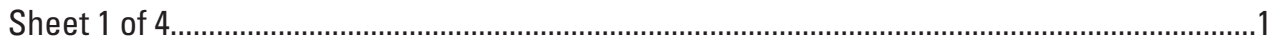

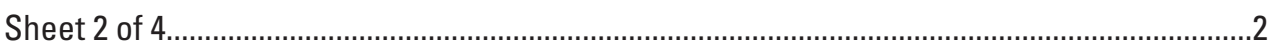

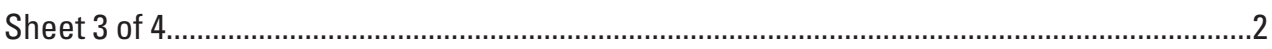

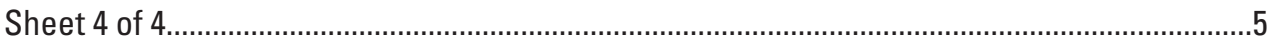

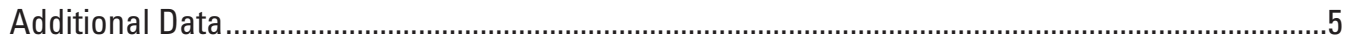

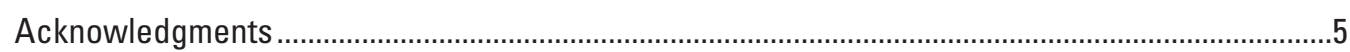

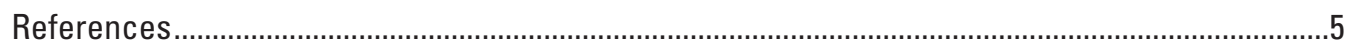

\section{Figures}

1. Propylitically-altered metavolcanic rock from the Excelsior Formation in the Wassuk Range southwest of Hawthorne, Nev. Note green chlorite and epidote .........................................3

2. Subset of sheet 1 overlain with geologic contacts from Crafford (2007). The neck of altered granite (Kfi) is clearly visible in red/pink hues surrounded by green-colored propyliticallyaltered metavolcanic rocks of the Excelsior Formation (WPL) .......................................................... 


\title{
Mineral and Vegetation Maps of the Bodie Hills, Sweetwater Mountains, and Wassuk Range, California/Nevada, Generated from ASTER Satellite Data
}

\author{
By Barnaby W. Rockwell
}

\section{Overview}

Multispectral remote sensing data acquired by the Advanced Spaceborne Thermal Emission and Reflection Radiometer (ASTER) were analyzed to identify and map minerals, vegetation groups, and volatiles (water and snow) in support of geologic studies of the Bodie Hills, Sweetwater Mountains, and Wassuk Range, California/Nevada. Digital mineral and vegetation mapping results are presented in both portable document format (PDF) and ERDAS Imagine format (.img). The ERDAS-format files are suitable for integration with other geospatial data in Geographic Information Systems (GIS) such as ArcGIS. The ERDAS files showing occurrence of 1) iron-bearing minerals, vegetation, and water, and 2) clay, sulfate, mica, carbonate, $\mathrm{Mg}-\mathrm{OH}$, and hydrous quartz minerals have been attributed according to identified material, so that the material detected in a pixel can be queried with the interactive attribute identification tools of GIS and image processing software packages (for example, the Identify Tool of ArcMap and the Inquire Cursor Tool of ERDAS Imagine).

All raster data have been orthorectified to the Universal Transverse Mercator (UTM) projection using a projective transform with ground-control points selected from orthorectified Landsat Thematic Mapper data and a digital elevation model from the U.S. Geological Survey (USGS) National Elevation Dataset (1/3 arc second, $10 \mathrm{~m}$ resolution).

Metadata compliant with Federal Geographic Data Committee (FGDC) standards for all ERDAS-format files have been included, and contain important information regarding geographic coordinate systems, attributes, and cross-references. Documentation regarding spectral analysis methodologies employed to make the maps is included in these cross-references.

\section{Overall Purpose of Maps}

The image maps were designed primarily for the regional mapping and characterization of hydrothermal alteration.
These maps are being used by the USGS in conjunction with new maps of the Tertiary volcanic rocks and other data to formulate a detailed geologic and metallogenic history of the Bodie Hills. Alunite detected using the ASTER data was sampled for geologic dating and geochemical analysis. As hydrolytic alteration commonly occurs along faults and fractures that serve as conduits for potentially metal-bearing fluids, the presence and type of alteration can provide important information for mineral resource investigations. The maps can also be used by land managers to assess vegetation cover for fire potential and animal grazing support, and by environmental personnel to evaluate pre- and post-mining effects of mineralized areas on local hydrology.

\section{List of ERDAS Imagine Raster Image Files Included in this Publication}

\section{Sheet 1 of 4}

Title: MINERAL AND VEGETATION MAPS OF THE BODIE HILLS, SWEETWATER MOUNTAINS, AND WASSUK RANGE, CALIFORNIA/NEVADA, GENERATED FROM ASTER SATELLITE DATA

\section{Subtitle: CONTINUOUS-TONE MAP OF MIN- ERAL GROUPS}

Filename: bor-sw_aster_contmin468_mosaic_pt-o3utm_7-09_cutline2_zfix.img

Description: This image consists of three enhanced, shortwave-infrared (SWIR) bands (4, 6, and 8) of a mosaicked ASTER dataset covering the study area. The three ASTER bands have been saturation enhanced and sharpened to $15-\mathrm{m}$ spatial resolution using edge-enhanced ASTER band 2 to modulate intensity. 
Purpose: The purpose of the image is to enable the visual discrimination of mineral groups and other surface features over the study area. When the provided bands $(4,6$, and 8 ) are displayed as a color composite $(468 / \mathrm{RGB}$, or $123 / \mathrm{RGB}$ for this dataset), the colors can be interpreted according to the following guide. Although most hydrolytic alteration minerals discriminated by the image (see magenta and red below) have diagnostic vibrational SWIR absorption features related to Al-OH bonds and (or) bound water molecules, Fe-OH bonds in minerals such as jarosite cause deep SWIR absorptions that may also be discriminated using the image. Si-OH bonds in minerals such as chalcedony also cause SWIR absorptions, but such quartz minerals are typically not discriminated using this image treatment.

Magenta: minerals with $\mathrm{Al}(\mathrm{Fe})-\mathrm{OH}$ or bound water SWIR absorptions (clays, sulfates, and white micas).

Red: minerals with $\mathrm{Al}(\mathrm{Fe})-\mathrm{OH}$ or bound water SWIR absorptions + ferric iron +/- minor carbonate +/- dry vegetation. Dark red indicates green vegetation (brightness reduced by using the red wavelengths of ASTER band 2, in which green vegetation shows deep chlorophyll absorptions and is thus dark, to modulate intensity).

Orange to reddish orange: dry vegetation $+/$ - minor Al-OH minerals +/- minor carbonate.

Brown to reddish brown: green vegetation.

Yellow/Green: carbonate minerals (for example, calcite and dolomite) more likely yellowish; chlorite, epidote and (or) amphiboles with ferric/ferrous iron absorptions more likely greenish. Yellow indicates strong absorption in ASTER band 8, typical of unaltered carbonate rocks devoid of clay, mica, and ferric iron minerals. Green indicates absorption in ASTER bands 4 and 8 relative to band 6, typical of $\mathrm{Mg} / \mathrm{Fe}-\mathrm{OH}$ minerals such as chlorite and epidote which are common components of propylitic alteration. The absorption in band 4 of epidote and chlorite is caused by ferric and (or) ferrous iron. Dense, dry vegetation typically has less absorption (is brighter) in band 4 than chlorite and epidote, although it also has deep absorptions in band 8 .

White: High-albedo surfaces such as playas which may contain clays, micas, and (or) other minerals.

\section{Sheet 2 of 4}

Title: $\quad$ MINERAL AND VEGETATION MAPS OF THE BODIE HILLS, SWEETWATER MOUNTAINS, AND WASSUK RANGE, CALIFORNIA/NEVADA, GENERATED FROM ASTER SATELLITE DATA
Subtitle: MAP OF IRON-BEARING MINERALS, VEGETATION, AND WATER

Filename: bor-sw_aster_mosaic_fe-veg_8-09_pt-o3utm_rgbclus.img

Description: This image shows iron-bearing minerals, vegetation groups, and volatiles (water and snow) identified using ASTER data based on spectral similarity between image spectra and laboratory reference spectra of well-characterized materials and material mixtures.

Purpose: The purpose of the image is to display the spatial distributions of identified iron-bearing minerals, vegetation groups differentiated by variations in greenness and dryness, and volatiles (water and snow). The image has been attributed by pixel value with material identification data that can be queried in most image processing and GIS software packages.

\section{Sheet 3 of 4}

Title: $\quad$ MINERAL AND VEGETATION MAPS OF THE BODIE HILLS, SWEETWATER MOUNTAINS, AND WASSUK RANGE, CALIFORNIA/NEVADA, GENERATED FROM ASTER SATELLITE DATA

Subtitle: MAP OF CLAY, SULFATE, MICA, CARBONATE, Mg-OH, AND HYDROUS QUARTZ MINERALS

Filename: bor-sw_aster_mosaic_swir_pt-o3-utm_8-09_ rgbclus.img

Description: This image shows clay, sulfate, mica, carbonate, $\mathrm{Mg}-\mathrm{OH}$, and hydrous quartz minerals identified using ASTER data based on spectral similarity between image spectra and laboratory reference spectra of well-characterized materials and material mixtures.

Purpose: The purpose of the image is to display the spatial distributions of identified clay, sulfate, mica, carbonate, $\mathrm{Mg}-\mathrm{OH}$, and hydrous quartz minerals. The image has been attributed by pixel value with material identification data that can be queried in most image processing and GIS software packages.

Comments: Largest occurrences of advanced argillic alteration are the 10-km long, west-northwest-trending Red Wash Creek alteration zone near the East Walker River; a west-northwest-trending zone $14.5 \mathrm{~km}$ in length in the Wassuk Range just north of the Borealis/Ramona district; on East Brawley Peak south of Aurora; and in the western Bodie Hills 4-5 km south and southeast of Bridgeport, Calif. Another west-northwest-trending zone containing significant 
alunite and kaolinite passes through the center of the Masonic district. This zone grades southward into phyllic/argillic alteration on Masonic Mountain. Most of these alteration zones have been detected and mapped using Landsat Thematic Mapper data (Rockwell, 1989). Intense phyllic, argillic, and local advanced argillic (alunite) alteration was identified in the Sweetwater Mountains. Sericite, local chalcedonic sinters, peripheral propylitic alteration, and minor clay (kaolinite with possible smectite mostly associated with mine waste and tailings) characterize the low-sulfidation mineralization at the Bodie deposit. Calcite, chlorite, epidote, and local sericite were identified in the eastern Wassuk Range 9-10 km southwest of Hawthorne, Nev. within the Triassic/Jurassic Excelsior Formation, which is mainly composed of limestones and clastic rocks intercalated with metavolcanic rocks including hornfels, greenstones, and more felsic units (Crafford, 2007;
Ferguson and Muller, 1949). These minerals represent propylitically-altered metavolcanic rocks (fig. 1) adjacent to intruded Cretaceous granite. The mapped propylite surrounds a small exposure of weakly altered granite containing identified primary sericite and secondary ferric iron, kaolinite, and possible smectite. This neck of granite is clearly visible on sheet 1 (fig. 2). In this area, the Excelsior Formation is in turn surrounded by the granite and Miocene(?) to Jurassic diorite (Crafford, 2007) suggesting that the Excelsior Formation is present as a roof pendant to the granitic intrusion. The dark green color of the propylite in sheet 1 is suggestive of propylitic alteration rather than carbonates, which typically appear in yellow to yellow-green in this image treatment. Recrystallized limestones of the Excelsior Formation appear yellow-green west of the Lucky Boy mine (fig. 2), and have pinkish hues where argillized. Small occurrences of calcite,

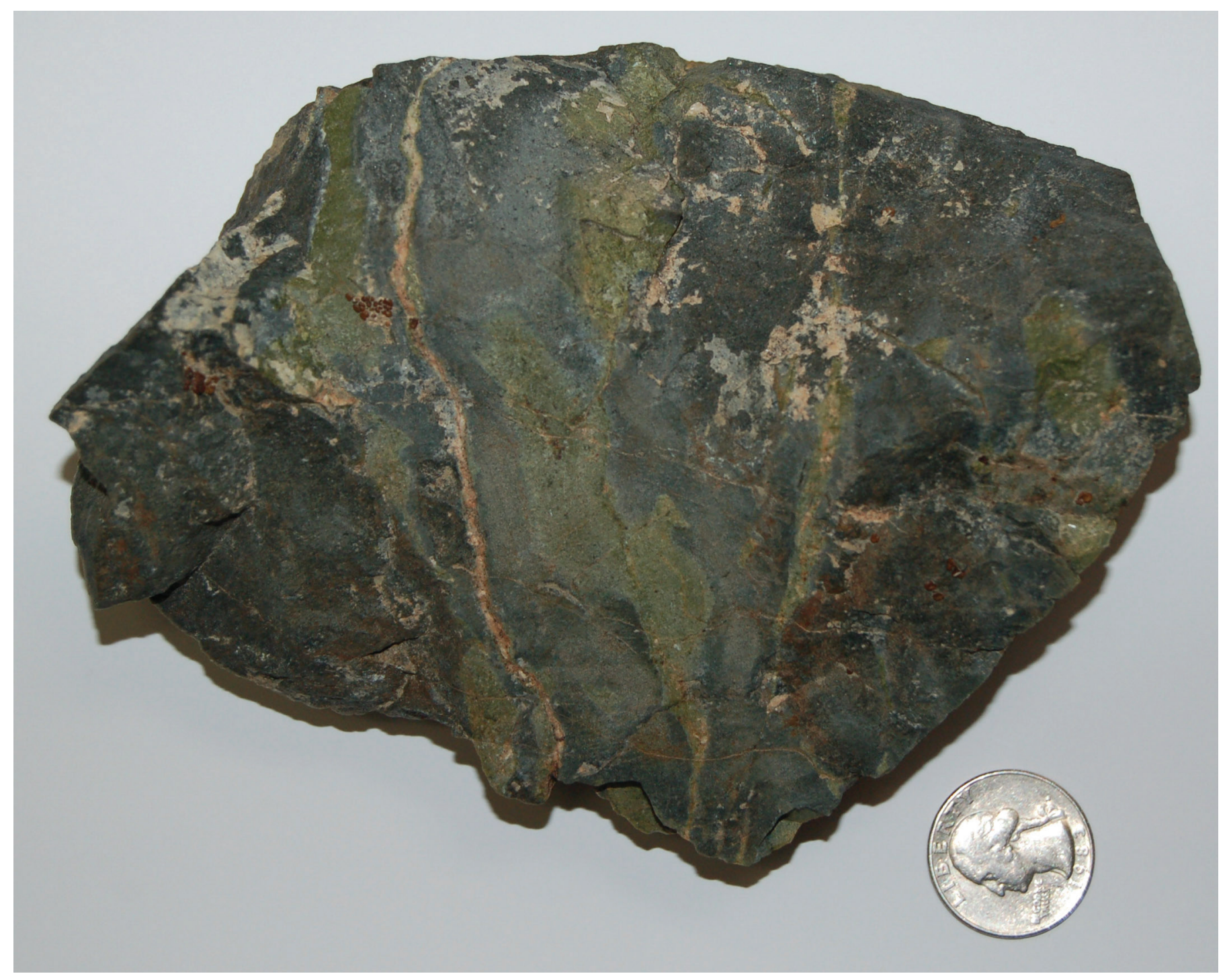

Figure 1. Propylitically-altered metavolcanic rock from the Excelsior Formation in the Wassuk Range southwest of Hawthorne, Nev. Note green chlorite and epidote. Sample WSK09-1 collected at 118.689513 W., 38.449715 N. (WGS 84). 


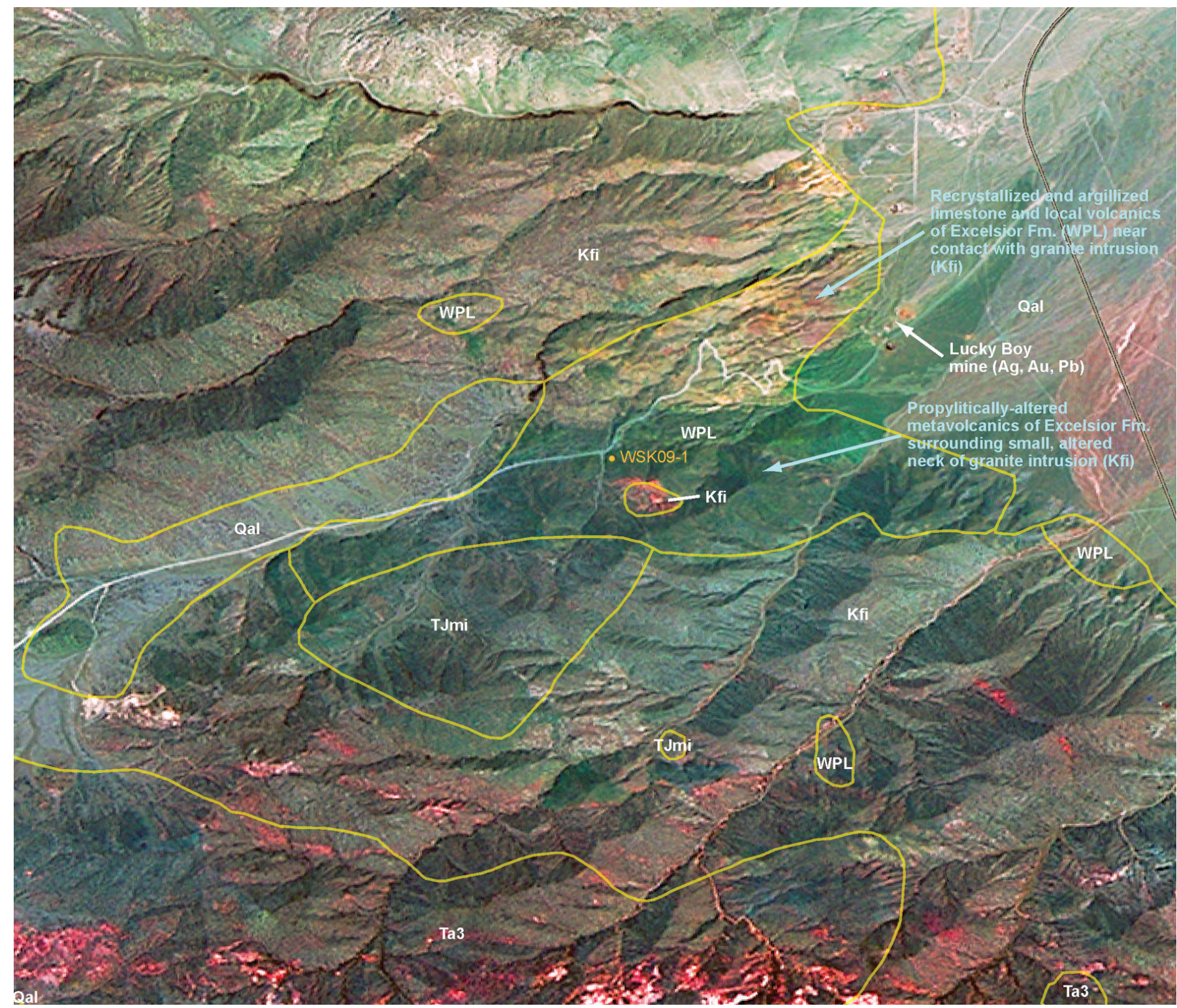

Figure 2. Subset of sheet 1 overlain with geologic contacts from Crafford (2007). The neck of altered granite (Kfi) is clearly visible in red/pink hues surrounded by green-colored propylitically-altered metavolcanic rocks of the Excelsior Formation (WPL). The sampling location of sample WSK09-1 (fig. 1) is shown. 
alunite, kaolinite, and pyrophyllite were identified at the Travertine Hot Springs two km southeast of Bridgeport, Calif. The advanced argillic minerals identified there using the ASTER data have not been field verified, although nontronite (an iron-rich clay mineral in the smectite group) with a primary $\mathrm{Al}-\mathrm{Mg}-\mathrm{Fe}-\mathrm{OH}$ absorption feature at 2.298 microns was identified in hand sample, as were opal, montmorillonite, and calcite.

\section{Sheet 4 of 4}

Title: MINERAL AND VEGETATION MAPS OF THE BODIE HILLS, SWEETWATER MOUNTAINS, AND WASSUK RANGE, CALIFORNIA/NEVADA, GENERATED FROM ASTER SATELLITE DATA

$$
\begin{array}{ll}
\text { Subtitle: } & \text { MAP OF QUARTZ ABUNDANCE } \\
\text { Filename: } & \text { mosaic_quartz_pt-o3-utm_rgbclus.img }
\end{array}
$$

Description: This image shows the spatial distribution and relative abundance of quartz identified using ASTER thermal-infrared surface emissivity data based on a compoundband ratio.

Purpose: The purpose of the image is to display the occurrence and relative abundance of quartz. Pixels with a non-zero value indicate identified quartz, and the brightness of the red color in the integrated color table indicates relative quartz abundance.

Comments: Greatest quartz abundance (brightest red) is of hydrothermal origin and occurs on in-situ outcrops. Quartz in lower abundance occurs mainly as alluvium in basins, and typically represents eolian sand deposits or coarser gravels and other basin fill derived from quartz-rich source rocks. Some quartz in low to moderate abundance was detected in nonporphyritic quartz monzonites along the East Walker River.

\section{Additional Data}

An ESRI polygon shapefile indicating areas of corrupted ASTER shortwave-infrared data is also provided in a .zip file (ASTER_swir_scratch_2scene_shapefile.zip). The zip file also includes the associated metadata.

\section{Acknowledgments}

The author would like to thank Eric Anderson and Peter Vikre of the USGS for their helpful reviews of the maps and digital data.

\section{References}

Crafford, A.E.J., 2007, Geologic map of Nevada: U.S. Geological Survey Data Series 249, scale 1:250,000, http://pubs. usgs.gov/ds/2007/249/.

Ferguson, H.G., and Muller, S.W., 1949, Structural geology of the Hawthorne and Tonopah quadrangles, Nevada: U.S. Geological Survey Professional Paper 216, 55 p.

Rockwell, B.W., 2009, Comparison of ASTER- and AVIRISderived mineral and vegetation maps of the White Horse replacement alunite deposit and surrounding area, Marysvale volcanic field, Utah: U.S. Geological Survey Scientific Investigations Report 2009-5117, 31 p.

Rockwell, B.W., 1989, Hydrothermal alteration mapping in spectral ratio feature space using TM reflectance data: Aurora mining district, Mineral County, Nevada, in Proceedings, International Symposium on Remote Sensing of Environment, Seventh Thematic Conference: Remote Sensing for Exploration Geology, v. 7, p. 1189-1203, Calgary, Alberta, Canada, October 2-6, 1989, Environmental Research Institute of Michigan, Ann Arbor, Michigan, USA.

Rockwell, B.W., and Hofstra, A.H., 2008, Identification of quartz and carbonate minerals across northern Nevada using ASTER thermal infrared emissivity data-implications for geologic mapping and mineral resource investigations in well-studied and frontier areas: Geosphere, v. 4, no. 1, p. 218-246, doi: 10.1130/GES00126.1.

Silberman, M.L., 1995, Road log from Hawthorne to Aurora and description of the Aurora district, in Jones, E., ed., Geology and ore deposits of Bodie Hills, northern Mono Basin region, Bodie Hills, Aurora District; Geological Society of Nevada Special Publication, no. 22, p. 16-20.

Smailbegovic, A., 2002, Structural and lithologic constraints to mineralization in Aurora, NV and Bodie, CA mining districts, observed and interpreted with aerospace geophysical data: Reno, University of Nevada, Ph.D. dissertation, 271 p.

Ward, J.M., 1992, The Cinnabar Canyon sulfur deposit, in Wessel, G.R., and Wimberly, B.H., eds., Proceedings of the 1992 annual meeting of the Society for Mining, Metallurgy, and Exploration; Native sulfur; developments in geology and exploration, Phoenix, Arizona, February, 1992, p 159-164. 